\title{
"From psychology in Africa to African psychology": Going nowhere slowly
}

\begin{abstract}
This provocation reimagines the dominant indigenisation discourse of psychology in South Africa, which conceives the process of "decolonizing" as equivalent to "Africanizing". I argue that some African psychologists' indefatigable insistence on narrow localism and ethno-theorising, is a cowardly defeatism and an accessory to domination. The in toto refusals of Western psychology, are themselves ahistorical and totally ignorant of the historicity and historical anteriority of Africa in science. Western knowledge is neither monolithic, nor the sole property and prerogative of the West. Africa has significantly contributed to its creation and should admissibly make foundational claims on it. I gesture at a different decolonial ethics, grounded on the Dusselian transmodernity, pluriversalism and ethical universalism, to negotiate the incongruous obscure particularism of some African psychologists, and also disabuse modernist psychology of its false universalisms. The paper reads ultra-essentialist responses to modernism as still being intrinsically Eurocentric, in that they have rather ironically continued to reinforce the process of "Othering" and negating through their fixation with identity politics and cultural reductionism.
\end{abstract}

\section{Introduction}

"Provincialism? Absolutely not. I'm not going to confine myself to some narrow particularism. But nor do I intend lose myself in a disembodied universalism. There are two ways to lose oneself: through walled-in segregation in the particular, or through dissolution into the 'universal.' My idea of the universal is that of a universal rich with all that is particular, rich with all particulars, the deepening and coexistence of all particulars" (Cesaire, 2006: 84).

\section{Malose Makhubela}

Department of Psychology

University of Pretoria

Pretoria

\section{Keywords}

African psychology, decolonization, modernity, transmodernity 
The formation of the Forum of African Psychology (FAP) division by the Psychological Society of South Africa (PsySSA) in 2009 has reanimated the politics of the relevance of psychology in South Africa, that had been thought to have in part been negotiated by the intervention by Nsamenang (1990) and the then Journal of African Psychology in 1990 and 1991. The name change of the then Journal of African Psychology to the now Journal of Psychology in Africa had aimed to somewhat negotiate the epistemological, ontological and ethical absurdities of ethno-theorising, especially as practised by some anti-universalist African psychology scholars in their response to modernist mainstream psychology. Decolonial psychologists in Africa, as Moll (2007) observes, are generally of two persuasions - those who view psychology as an indigenous area of study marked by distinctive worldviews and lived experiences of the continent (for example, Akotia \& Olowu, Baloyi, Bodibe, Matoane, Mbiti, Mkhize, Nobels, Nyasani, Sodi, Tempels, etc), and those who see it as a universal disciplinary practise predicated on and concerned with psychological affairs of Africans yet whose postulates traverse cultures and race (for example, Akbar, Dawes, Fanon, Gulerce, Hountondji, Moll, Mashegoane, Nsamenang, Nwoye, Okpara, Ratele, etc). Ratele (2016) offers an alternative characterisation of Africa(n)-centred psychology, through what he terms "four psychologies", namely, African psychology as psychology in Africa; as cultural African psychology (traditionally, metaphysically or spiritually disposed); critical African psychology (offering a materialist and political reading of psychological issues); and psychological African Studies (psychologically attentive African Studies). I imagine that these portrayals are not inarguable or fixed and that there will be contestations among scholars on the abovementioned characterisations of psychologies in Africa and that there may exist more modes of organising this field, but the aforementioned will suffice for the point I want to explore herein. Also, by this account, I claim to by no means tender a terse genealogical review of decolonial psychology in Africa, but underline the fact that (South) African psychology's decolonial movement is not a monolithic area but a contested space. This is despite the fact that the movement is currently dominated by ethnographic scholars (the former stated tendency by Moll). While the two persuasions (if using Moll's broad characterisation) have areas of concordance, especially on the problem of modernist/mainstream psychology, there are however significant differences in strategies on how to respond to it. Ratele (2016: 5) underscores this fact, in his observation that: "whereas African psychology is the umbrella term that can be given to the broad terrain of work conducted by psychologists in Africa, the territory is in fact divided into different epistemes, approaches, perspectives, and orientations towards two principal objects: psychology and Africa". One issue, though, that threatens to reduce the influence and significance of ethnographic scholars in psychology in Africa is that of their insistence at ascribing a distinct kind of "mentality" to the peoples of Africa. These attributions have generally resulted in a double standard that defines Africa's indigenous cultures and civilisations as being somewhat intellectually substandard. 
Ethnopsychology is also seen by many as merely being a description of passively held African indigenous beliefs and practices (and folk knowledge) rather than an attempt to present, theorise and critically appraisal them- a process of intellectual enterprise that is normative in academic/scientific psychology. By seeking to negate Western psychology with folk psychology, ethnographic African psychologists actually provide credence to the regrettable practice, common in colonial scholarship, of pitting Western science against African folk traditions instead of comparing similar things. I shall return to these issues in detail later.

The predicament of appropriateness and the exhaustion of mainstream psychology in South Africa today emanates from the perpetual crisis of the current Eurocentric modernist academic traditions. These pervasive scholarly traditions are a corollary of the spurious universalism of the European Enlightenment and epistemic solipsism. However, this Kantian model of knowledge creation has long been rejected by some in the Global South, North American and European postcolonial academy, due to its complicity with epistemic racism (Dussel, 2008a; Mbembe, 2015). There is a total rebuttal of the credo that only hegemonized European traditions of knowledge are adept at attaining universality. Controversial about this tradition, is the sagacity and facticity of total encyclopaedic-anthropological knowledge, the farce of knowing about the "Other" that denies the "Other" as thinking and knowledge-producing subjects. This academic tradition is also seen as punctuated by ideological myths reflective of their colonial and racist heritage (i.e., the superiority of whiteness) and the odious falsification of human history. Although some currents like psychoanalysis, critical and community psychology have long been critical of these premises, variants of these streams still tend to unconsciously produce knowledge from a zero-point philosophising (Fanon, 1986; Castro-Gomez, 2005) that does not question the sociogenesis of the knowledge they produce and the place from which they theorise (de-socialized and de-historicized knowledge).

Clearly, it is inarguable that there is everything tragic with, for instance, a psychological science designed to meet the ends of colonialism and Apartheid continuing well into the post-Apartheid era. Mainstream psychology in South Africa is seen as harbouring aspirations of becoming a local incarnation of an imperialist academic model based on a Eurocentric epistemic standard, which discounts and represses other epistemic traditions. And as such, the renewed consensus that psychology as an institution must undergo a process of decolonization to deal with the false universalism of westernised/modernist theorising are welcome. Of course, mainstream psychology in South Africa needs to overcome its messianic and paternalistic complexes and open itself to other genealogies of thought that have been historically subalternized and illegitimately considered barren by the West. While there are some achievements accrued 
by this resurgent resistance movement, there are also many challenges consubstantial to it. This reinvigorated discourse, as agitated by some psychologists in Africa, has mostly taken a perverted tone, which is captured by a praxis that reifies ethnoscience, identity politics and narrow provincialism that it claims to negate. In addition, this new polemic has led to a narrow relativism, epistemic populism and the in toto rejection of all research-making claims of universality and western knowledge, where all things propounded by the subalternized are regarded to be valid.

This resurgent discourse is a forceful instantiation of a scholarly tendency among some psychologists in Africa to see psychology as an indigenous disciplinary enterprise, associated with the propositions and practice of African traditional healing, and that also totalise the psychology of the West. Tellingly, it is hard to fathom how this tendency can be a singular decisive instance of decolonisation of psychology in Africa. Dawes (1998: 9) underlines this error on the part of some psychologists in Africa by warning that: "We should also be careful to consider the type of theory and the components of a specific theory which might be problematic in a particular cultural context. Thus formal models of cognitive functioning, or explanations of pattern recognition, are likely to be less problematic than models of personality. The former provides explanations of more elementary psychological processes. They are less vulnerable to attack on grounds of Eurocentricity, because they are possibly closer to hardwired processes". Similarly, Nsamenang and Dawes (1998: 77) urge that: "In considering a liberatory project, it is important to identify the aspects of psychology that are problematic in a particular cultural context. For example, the Eurocentricism in Piaget lies not in his developmental theory of equilibration, but in his assumption of formal operations as an optimal form of reasoning. Even though rural African communities have different indigenous concepts of intelligent behaviour to those in Europe, this does not challenge Piaget's core construct". For instance, this motif can be evidenced in the 2014 FAP inaugural congress under the title "From psychology in Africa to African psychology" (read as folk psychology) that saw argumentations from the likes of Matoane (2014) on the need to reject psychological theories/theorising that adopt a universalist approach, and Sefotho's (2014) lamentations that the time to confer African ethnopsychology academic and practical relevance is long overdue.

It is also not uncommon at PsySSA congresses to hear discussions on witchcraft and its relevance for assessment, diagnosis and treatment of mental health conditions (Mhlongo, 2014), the relevance of knowing the African traditional healing systems in the practice of mental health (Notshulwana \& Franklin, 2014), and of Swati traditional healers' conceptualisation of the causes and treatment methods for mental illness (Ngobe \& Sodi, 2015). Although the previously mentioned survey of works is not exhaustive, the abovementioned authors' central thesis is similar to several other scholars within this 
mould of African psychology, and will thus serve as examples for the purposes of this paper. My intention in this essay is in part, to demonstrate that this line of theorising is marked by a series of deep antagonisms, and fails to escape the artifices of identity politics and a narrow and closed particularism - that views African life as self-contained. Likewise, the established vocabulary and approbation of the locution "traditional" and "African", in some African psychology literature, compound the problem by invoking a particular essentialism. Mabogo More (1999: 336) makes the following observations about this issue: "the term 'African traditional' as Campbell Mamoh correctly objects to those who foist it, ripples with images of naiveté, stagnation, low intellect, superstition, magic, immutability, fixation, and non-progression. Instead of this ideologically loaded and contestable term, 'traditional' people such as for example Fanon and Mamoh, speak of 'pre-colonial' or 'Ancient' Africa". As it will be evident later, this paper will argue along the lines of Nsamenang $(1990 ; 1992)$ and likeminded African thinkers, that, ultimately, psychology is a universal undertaking rather than a parochial enterprise. Nsamenang's (1990: 1) warning that the: "fragmentation of psychology by its 'variants' with particular peoples or geographic locales is unfavourable for evolving a coherent set of universally applicable psychological laws and does not support psychology's acclaimed status as a true science of the human organism, a global species" is still instructive even today.

Strangely, as Moll (2007: 7) puts it: "the greatest irony is perhaps that the philosophical psychology associated with the 'ethnographic school' ... with the pioneering work of Tempels and Mbiti, and with the strong versions of indigenous personality theory (Nyasani, Bodibe), owes most of its theories and methodologies to European anthropologists and missionaries who formulated the notion of 'collective philosophies of life' on which it is based". Long's (2016: 2) similar observation on the Africanization of psychology in South Africa is worthy of a long quote: "... because of the pervasive sentiment that the so-called 'African worldview' is sine qua non of African psychology, African philosophy has come to assume pre-eminent status in the field. Nowadays, it is neither unusual nor distasteful for an African psychologist to claim that Africans think like this, like that, or however the case may be. Yet it is overlooked with some regularity that this now established practice of homogenizing the African mind is forever indebted to the publication of the Belgian missionary, Placide Tempels' (1959) book, Bantu Philosophy, in which the churchman attempted to delineate a plan of action for 'civilizing' Bantus ... African psychologists have almost nothing to say about Tempels - he has been written out of the history of African psychology ... for Tempels, the civilizing imperative was of crucial importance to 'colonizers with good will' who would 'be able to tell them [i.e. Bantus], what their inmost concept of being is'". I must confess on the onset, that, I am always sceptical and unsettled whenever liberatory thought in Africa appeals or pivots itself on missionary logic and conceptions of what it means to be African, when attempting to undermine and unsettle colonialism, because the result is ironically just a reinforcement and 
the preservation of coloniality. In the next section, the reader is engaged on what is unsettling about this trend of African psychology scholarship.

\section{Decolonization as Africanization}

The dominant decolonial ideology in South African psychology gestates the process of "decolonizing" as equivalent to "Africanizing". This discourse is not new and has also not gone uncontested (see Dawes, 1998; Mashegoane, 1998; Nsamenang \& Dawes, 1998; Long, 2016). This ultra-essentialist theorising, by some African psychologists, is redolent of a relativism that reifies culture as the only determinant of behaviour and its psychological variants. Agitating for this movement, Matoane (2012a) asserts that indigenous psychology is intended at promoting the significance of the local culture in the understanding and resolving of psychological problems.

But, parochialism and nouveau-pragmatist rejections of broader normative claims are, in my view, a cowardly defeatism and an accessory to domination. The wholesale refusals of Western psychology are themselves ahistorical and totally ignorant of the historicity and historical anteriority of Africa in science (Diop, 1991). In any case, Western knowledge is neither monolithic nor the sole property or prerogative of the West. Africa has significantly contributed to its creation and should admissibly make foundational claims on it (Diop, 1991). A consummate appreciation of this fact compels one to travel back 5,000 + years to the historical foundations of psychology as captured in the Egyptian Mystery System's theory of salvation (Myers, 1988). The Kemite / Black educational system is the first movement of civilisation and was conceived out of the world view of ancient Africans (Myers, 1988). For instance, Greek philosophers such as Socrates, Plato, Pythagoras, Heraclitus, Parmenides, Democritus and Aristotle are noted to have studied in the Egyptian Mystery System, after the Persian occupation. Aspects of the philosophies and human sciences attributed to them were actually developed and taught by the Egyptians (Diop, 1991). Alexander's 322 BC conquest of Egypt marked a notable event in the proliferation of the Egyptian knowledge. Alexander and Aristotle are recognised to have emptied/stolen and destroyed the Library of Waset (Alexandria). And after the Edict of Theodosius in 529 AD and the closure of Egyptian temples, the Egyptian Mystery teachings stopped to exist and to be defined as such (Myers, 1988). The Greeks were influential in the populating of the Egyptian Mysteries to the Western world (Diop, 1991). Accordingly, a true decolonial project should actually go further and reassert Africa as the bedrock of Western knowledge and not relegate or consign it to the margins. We cannot advocate for decolonisation without recourse to reclaiming the primacy of Africa to the knowledges of the (Western) world. Preoccupation with the opposite, as some African psychologists tend to do, only betray their ignorance of the current historico-scientific evidence on this fact (Ogunmodede, 2006). Advocacy for this, on my side, is by no means a desire to "embrace and valorise the Western life-world 
and its values, language, science, philosophy ..." (More, 1999: 332) or a "yearning for assimilation of and into the spirit of Europe" (Owomoyela, 1996: $\mathrm{x}$ ), but a gesture to take back what is ours. Ngugi wa Thiong'o captures this observation in his agitation for the "re-centering" of Africa (Mbembe, 2015).

Also, ethno-theorising, as operationalised by some African psychologists, is still intrinsically Eurocentric, as it has rather ironically reinforced the process of "Othering" through its insistence on difference and identity politics (Dussel, 2008a). As such, anti-universalist "politics of difference" play into the game plan and master narrative of euro-modernism and unwittingly concedes to a notion of ontological exclusivity, where Africans are seen as being primitive, and only good for superstition, and that conscribe Africans to the periphery of reason and science. After all, much of this brand of Africanist scholarship's conception of colonialism, in our instance, settler colonialism, seems to be a morass of misrepresentation and betokens a significant misunderstanding, that colonisation did not only involve the insistence of settler authority over all life-worlds of the African by importation of alien modes of living and disruption of indigenous ways of being, but also mostly extended to the stealing of much of ancient Africa's critical knowledge archives and structures. So, decolonization-proper should attend to the seizing of imperial properties of conquest (stolen property) as an integral part of settlement. Scandalous as this assertion may sound, reclaiming "stolen property" and reasserting Africa's primacy to much of the West's archive and decolonisation are a singular commitment and should therefore mutually constitute one another. Making knowledge systems irreducibly local may also result in ahistorical reifications and fetishizing culture and the local (Alcoff, 2012). Fanon (in, Mbembe, 2015: cf 10-12) argues that this is a "retrogression" that will only lead us astray. While Fanon (1986) is credited to have formally, in psychological terms, initiated the study of the "African personality" in his psychoanalytic thesis on domination, he however located it within a global science and as a necessary part of the world's psychological science.

Reading Fanon, Okpara (cited by Moll, 2007: 4) submits that while there are unique psychological characteristics in Africans, however, "such an argument does not suggest, a priori, that 'personality'.... has an African texture or a European texture ... Evolution has not created two different minds - one for Europeans, another for Africans". Fanon argued that the cultural aspect of the African personality is irrelevant unless there is a political and social component to it and located within the global condition of the human being (Wilson, 1999). Wilson (1999: 118) reemphasises Fanon's point when he states that: "culture is not static ... Culture itself must reconstruct itself if the system in which it exists is reconstructed and rearranged. Some of us (African-centred psychologists) get in trouble because we want to find an African culture stuck somewhere back in the thirteenth century and want to apply it to ourselves at this point in a different context ..... Epistemological and 
ontological commitments propagated by this ethnographic corps of African psychologists, are obviously problematic in that they have led to: 1) the continued reducing of culture and psychology to folklore [e.g., Morokane, Baloyi \& Siswana's (2015) argument for "the role of indigenous songs in psychology"] (what Hountondji terms folklorism); 2) the contradiction of appropriating universal concepts and phenomena to exclusively explain psychologies of Africans (e.g., communalism); and 3) the entrapment of African psychology by the metaphysical and spiritual/transcendental.

Dawes objects to this established tendency of conflating folk psychology and philosophy with scientific and academic psychology. He argues that: "A formal psychological theory is not a folk model. Folk concepts involve everyday commonly held conceptions of mentality and causes of behaviour. Psychological theory provides a systematic higher order account of an aspect of mental functioning, formulated, critiqued and researched according to sets of rules which bind the research community. This makes it different from a folk theory, which is not formalised and in most contexts invokes authority or public opinion in order to warrant its claims. All communities, including modern societies, have folk theories about mentality and behaviour and it is important that these be understood on their own terms ... formal psychological accounts differ from everyday accounts by virtue of their attempts to go beyond such everyday explanations" (Dawes, 1998: 10). Another case in point, is the pervasive reductionism of always been tempted to explain almost all psychological suffering through ancestral calling, wrath and witchcraft (see Madu, 1997; van Dyk \& Matoane, 2010; Juma, 2011; Matoane, 2012b; Mkabela, 2015). What part of witchcraft can we claim to be solely and exclusively African to the extent that it uniquely explains our psychological existence? Do other parts of the world also not have witchcraft or black magic? But 500 years ago, witchcraft was a major cultural phenomenon in Europe and it still persists in some parts of its society. Why do we view practices that are evidence of the stagnation of Africa due to Western imperialism as being truly characteristic of African life? Likewise, what is the relationship between traditional healing and African psychology? Are African psychologists both traditional healers and psychologists? It would appear that traditional healing has become synecdochic for African psychology in this discourse.

For instance, Baloyi (2014) explains that Masters clinical psychology students are expected to interview and observe traditional healers doing their work as part of their training as African psychologists at both the University of South Africa (UNISA) and University of Limpopo (Medunsa). Now, this trend of African psychology discourse, as I have already alluded to, is singularly complex and contradictory, and includes within itself sources of its own rebutting. Much of its rallying philosophies (i.e., Communality ( Ubuntu) are themselves not unique to Africa but are universal and relevant to other cultures of the world. Baloyi and Makobe-Rabothata (2012: 234) averred thus, when 
arguing for the particularity of communality to Africans: “... that in the main, there are things uniquely African, shared by African conceptual frameworks and cultural practices which espouse the African reality which is different .... But appropriating universal concepts like communalismb / Ubuntu (see Kamwangamalu, 1999), and phenomena like witchcraft to exclusively describe African life and psyche is in itself a contrafactual imposition. Asians and South Americans also observe an anthropocentrism that is communalist, as such Africans cannot exclusively claim this worldview. After all, this can only prove that African experiences are universal experiences, shared by other human beings and not as unique as some in the current African psychology discourse would want us to believe (see Somni \& Sandlana, 2014).

How do we speak of an African culture as if it is a pure, homogeneous and monolithic phenomenon? Through colonisation and globalisation African "cultures have become diluted; hence, one very rarely encounters a pure, traditional African culture" (van Dyk \& Nefale, 2005: 49). Communalistic values have already withered in most African societies. Communalism is less observed in urban African communities than in rural African societies (Kamwangamalu, 1999). So how do we arrive at it being the cornerstone of our theorising and understanding of the African psyche? One of this brand of African psychology's supposed tour de force, Ubuntu therapy, has thus far not been able to stand on its own. van Dyk and Nefale (2005: 55-56) grudgingly acknowledges and describes Ubuntu therapy thus: "The Ubuntu model of psychotherapy that we propose embraces these Western theories and techniques and attempts to adapt them to the African clients' unique situation and context, often calling for an integrated approach to psychotherapy". It relies on most Western theories and therapies (e.g., systemic and client-centred approaches) to understand its subject and to also meet its ends. Would this not be simple heresy, given that this trend of African psychology's rallying principle is that of the complete rejection of Western psychology? This is a prima facie contradiction. Does the motif of this mould of African psychology ground itself in any perspective? Does any of this movement's proponents critically spell out its foundational views (epistemological and ontological)? What theories of human nature do they espouse and whence do they originate from? Do they have a theory that can also explain the dark sides of African personality, and not only see all the good in the past and present Africans? Do they have a theory of personality rooted in the origins of the human species? What is this type of African psychology's view concerning the monogenetic theory of the human species, what value do they attach to such a view and how does it impact their theorisation? These questions still remain. As DuBois (1940) asserted, decolonization-proper fundamentally centres on "the destiny of humankind" and not of one race. This view is also shared by like-minded scholars such as Mashegoane (1998: 20), who reasoned thus: "indigenization which does not adhere to the principle of the monogenetic evolution of the human species violates the law of the common heritage of 
mankind ... Indigenization does not have to invoke and adopt the ethnocentrism that it purports to destroy". As such, nationalist solutions to the global coloniality of power are, in my view, inherently derisory, if not defeatist. After all, knowledge produced in Africa is inevitably part of a universal knowledge system (Nsamenang, 1992; Moll, 2007).

This brand of African psychology will have to resolve its manifest double confusion, both theoretical and political, for it to be taken seriously and to shore off the attribute of it as a mad incantation that largely survives in its academic redoubts. It is assertions like the following: "Properly constructed, like a mirror, psychology as a field that deals with diverse people's experiences, should reflect these different realities in the curriculum, not universalized reality" (Baloyi, 2014: 7), that punctuate the ideological disorientation and the incongruity I speak of. Another like-minded ethnographic scholar continues along the same line when describing indigenous African psychology: "It focuses on indigenous African culture as a paradigm for the study of African behaviour ... Consequently the indigenous psychological theories are constructed on the basis of values and concepts of the target culture; they represent the viewpoint of insiders", she goes further: "indigenous psychology should also be understood in the context of the multicultural realities of South Africa. The African paradigm serves as a liberating intellectual movement towards a pluralistic perspective in psychology" (Mkabela, 2015: 286). Sadly, this has culminated in some antithetical logic of calling for "plurality" in the body politic but in the same vain obsessively and vigorously embracing self-contained particularism. For example, Baloyi (2014: 7) charges Western psychology of advocating for a "Uni-knowledge (uni-psychology) instead of multiple epistemes / pedagogical diversity". But, is this not exactly the same blunders that this type of African psychology is committing? The current social character and ideological impulses of this brand of African psychology betray the same emancipatory fantasies that drive it. Here, one has, to borrow from Žižek, to "traverse the fantasy" and agitate for a polity that does not seek to obfuscate the problem but confronts it directly.

The decolonial psychology in question in this paper, as actualised by nearly all the above cited authors, with very few exceptions, represents a contradictory space within which a quasi-hegemonic discourse (identitarian and cultural reductionism) and a counter-hegemonic one (pluriversality) coalesce and are somehow collapsed into one. It is commonplace to find authors within this ethnographic tradition claiming to be championing pluriversalism in their calls for ethnoscience, provincialism and anti-universalism. This callous disregard for theoretical rigour leads to at least two problematics and has far reaching ramifications that I can only fleetingly indicate here: a) calls for the Africanization of psychology appropriate a status of a fetish rather than a compelling model of practical reason, and b) the problem of identity politics of a militant identitarian nature, that Dussel's theory of pluriversality / transmodernity 
offers much skewering against. This type of identity politics is complicit with the ethnic/racial hierarchies of Euro-modernity-capitalism complex and leaves the state of affairs untouched. It leads in one's emphases of their own racial group, complacent self-absorption and, consequently, the regarding of one self as being in constant competition with other groups that are similarly segregated against, thereby advancing the proliferation of a system of divide and rule, and relatedly ethnic/racial hierarchies. These are somewhat esoteric abstractions but I hope that they will become discernible as I continue.

It is apparent that, although the idea of pluriversality is flirted with and peddled about by the said scholars, there is much in this concept that is misunderstood, especially the key tenets of the theory of pluriversality (i.e., aspirations for true universalism) as fathomed by Dussel. As I see it and I will show later, the inanity of their discourse is exemplified by their more than oxymoronic calls, and the fact that provincialism and identity politics are prized more than pluriversality-proper by these scholars. The succeeding last two sections, will attempt to briefly address Dussel's (and to some extent, related authors) far reaching ideas on pluriversality / transversality and illuminate their often ignored and less appreciated workings and meanings. It is hoped that these sections, especially the last one, will offer a better premise on what it means to be pluriversal, its epistemological and historical foundations and also attend to the meta-philosophical question of what makes pluriversal knowledge pluriversal, as reflected in Dussel's work. For me, this ideologically laden notion of pluriversality can only truly be understood through considerations from Dussel and any contrary, wanton use and untroubled invocation of it betrays the epistemological foundations consubstantial to it.

\section{Decolonization as pluriversalism}

Decolonizing psychological science should therefore not merely be about deWesternization. Boidin, Cohen and Grosfoguel (2012) argue that a reproach for epistemic coloniality does not necessarily equate to the wholesale denial of all research-making claims of universality and the Western archive. Psychology in Africa ought to "shed its petty, overused monocultural coat and develop into a universal science" (Nsamenang, 1992: 218) for it to properly serve its subjects. As such, calls for "the move from Universalist understanding of human behaviour to a culture informed" by Baloyi and Makobe-Rabothata (2012: 241) should be untenable. In fact, latest reflections on this matter underscore the need for a process of "ethical" universal thinking in knowledge production, which is anchored on pluriverses of knowledge or epistemic diversity (Mbembe, 2015). This can only take effect when knowledge production and structures of non-Western critical traditions and genealogies of thought are fully acknowledged and embraced. Boidin et al (2012: 2) assert that "Far from limiting itself to a weak relativism by default, or to micro-narratives, the decolonial proposal would 
be to search for universal knowledge as pluriversal knowledge, but through horizontal dialogues among different traditions of thought, or in Dussel's terms transmodernity as pluriversalism". It is exactly this suggestion that I appropriate to attempt to assist us transcend the anti-universalist / universalist psychology debate in South Africa.

Here, I propose we seek recourse in the replacement of epistemic coloniality and provincialism for heterodox thought that is embracive of genuine pluriversalism. This notion draws upon the Argentinian-Mexican theorist Enrique Dussel's work on the ethics and philosophy of liberation. Burton and Osorio (2011: 21) have already made a case for the extension of Dussel's work to psychology by suggesting that "... the whole discipline of psychology itself is co-constituted with the Eurocentric modernist project for which Dussel's work offers a new perspective and corrective, especially through his proposals of trans-modernism and analectics". However, calls for theoretical pluriversalism / transmodernity are not new to psychology in Africa (see Serpell, 1992; Seedat, 1997; Dawes, 1998; Mashegoane, 1998; Nsamenang, 2002; Nwoye, 2015, for examples). While Mashegoane (1998) conceived of this process as coequal development and equal appreciation of modern and traditional sectors, Seedat (1997) argued for epistemological pluralism in psychology in South Africa. Similarly, Dawes (1998) urged that African psychology should pivot itself on both local and external episteme rather than essentialist practices that result in trivial outcomes and the forestalling of the decolonisation of psychology. Ratele (2016) also encapsulate this position, when he speaks of the development of a world-centred psychology conscious of its location and situatedness in Africa.

This suggestion should be possible according to Mashegoane (1998: 64) because: "that psychology has established itself as a universal science, being taught and practised in many countries around the world, is not under contention" and therefore its principles should transcend national limits. Dussel for instance makes it clear that knowledge can only truly be assumed to be universal if it is by definition pluriversal, and the inverse is also true. Nwoye's (2015: 105) conception of what psychology in Africa should be, is also apt: "African psychology, in my view, should be understood as a bothand psychology; that is to say, as an inclusive psychology encompassing not only the study of African indigenous psychology but also the study of the human condition and culture and the life of the mind in contemporary Africa, as well as the exploration and adoption, where necessary, of aspects of western psychology that appear relevant for enabling us to confront the challenges of our present African predicament". His African psychology is a psychology that is founded on pluri-formic or varied epistemological conventions. He underscores this point by offering the following definition of what psychotherapy in Africa should be: "the study and application of the best practices in Western and indigenous psychological therapies to the amelioration of the 
psycho-social wounds and damages, and stresses and challenges of the post-colonial Africans .... psychotherapy in Africa is an umbrella term for making references to the pluralistic psychological methodologies ..." (Nwoye, 2010: 28). This sentiment also finds resonance with the diasporic movement for African psychologies.

For instance, the esteemed Na'Im Akbar (1984: 411-412) proffers the following portrayal of Africentric psychology: "The Africentric approach assumes a universal knowledge of the make-up of the human beings themselves ... Although the model is based upon the tenets of traditional African philosophy, it does not exclude in its fundamental assumptions the possibility for normative activity on the parts of people of other ethnic origins. The new paradigm in fact formalizes and provides a context for many of the issues that are increasingly being raised by Western social scientists themselves. Theorists such as Abraham Maslow, Rallo May, Alan Watts, and many others out of the existential and humanist schools have addressed many of the same issues that are raised within the Africentric context and are resolved within the Africentric model". I am inclined to think that the main purpose of the decolonial project in psychology would entail making psychology relevant to Africa rather than making Africa relevant to psychology. The former raises questions of the content of psychological knowledge and the latter the issue of the method. What is at stake here is the content of psychological knowledge (that should attend to African psychological interests) and not necessarily the method. Therefore, psychology in Africa should be held to the same analytic standards as scientific/academic psychology. This will assist us to overcome problems that characterize some ethnographic scholars' attitudes on Africanisation. Such as, the belief that critiquing the relevance of mainstream psychology implies a total rejection of it (content and methodology) and the habit of countering of Western psychology with folk psychology.

\section{Dussel's trans-modernity as pluriversalism}

Predicated on two conceptions, analectics and ethics of liberation, Dussel's oeuvre grants us an epistemological and political opportunity to navigate the limitations of modernism and all essentialist contradictions. He explains his intervention this way: "What is really happening is that what I am talking about is 'post' all this. Mine is an antidogmatic universalism. It is a claim to universality that cannot be the 'old' Eurocentric universalism" (Gomez \& Dussel, 2001: 63). Dussel accomplishes this by positing a total devotion to the excluded "Other" and exteriority as a means to upsetting and negate modernism with transmodernity. His propositions and preceding arguments are intimately linked with the process of de-colonialisation and intercultural interlocution.

Dussel retools negative dialectics of the Frankfurt school into ana-dialectics to explore his ideas of the alterity of the Other and transmodernity. Montero (in Burton 
\& Osorio, 2011: 26) describes Dussel's analectics: "as the extension of the dialectic ... as a 'moment of the dialectical method' that incorporates a new possibility in the construction of knowledge: the excluded Otherness or alterity of those who not only are different (as complementary antitheses of that which is opposed), but foreign, strange (extraños), different, unexpected, external. It supposes accepting as knowing subject someone not imagined, someone not equal". For Dussel (1985) analectics positions every person and all racial/ethnic groups beyond the ambit of totality. His is a liberatory ethics that asserts the human alterity of the historical Other, by negating their negation. For Burton and Osorio (2011), Dussel provides us with a solution to the central problem of ethnocentrism.

Furthermore, Dussel's transmodern analectics, as Burton \& Osorio (2011: 30) observe, can offer us “... a defensible psychological science - not just ... psychology as a critique, but ... set of practices that collaboratively create new and dependable knowledge". That is, "... a historical utopia of life, a planetary, global 'transmodernity', a 'new civilisation' as 'realiser of the values' of 'the barbarians' of those from 'outside', that includes a redefinition of the relation between person and natural world as an ecological re-creation, and the relation between persons as cultural, politico-economic justice ..." (Dussel, 2002: 63). Dussel understands the potentiality in transmodernity to influence us to transcend traditional dichotomies so omnipresent in the psychological discourse in (South) Africa, to develop an ethical universalism beyond nationalism and colonialism; to create knowledge beyond third world and Eurocentric fanaticism; to articulate a praxis with the Other- a radical universal decolonial anti-capitalist politics beyond identity politics and to overcome reductionism and culturalism.

\section{Conclusion}

The argument for epistemic diversity, ventured in this essay, should not be mistaken for that of an "epistemic liberal multiculturalism" (ideological pacification in the Žižekian sense), where every subalternized epistemic character is represented, leaving intact the epistemic racist privilege of Western theorising so ubiquitous and palpable in South African psychology. Nor is it the uncritical call for the asymmetrical internationalizing of psychological knowledge, as championed by the International Union of Psychological Science that has retooled and repackaged the false universalisms of the modernist Enlightenment- through the summary and indiscriminate transferal and globalization of Western psychologies, without any reciprocal exchange of knowledge from other genealogies. Instead, this suggestion aims to defeat the parochialism of Western epistemology and the invisibility it produces on the social-historical experience of the African subject. This is also not a desire for a relativism of everything is permissible, nor an epistemic populism where all things said by the subalternized subject are readily taken to be authentic knowledge. 
For example, the continued equating of African psychology to traditional healing, and the use of folklorism and ill-defined adulterated and vulgarised African concepts like Ubuntu as grand theories in some African psychologists' work require critical engagement. The advancement of communalism and the so called "African world-view" in psychological theorising in Africa should therefore be critically appraised, especially given the missionary history whence the notion originates from (Tempels). While the significance of communality to traditional African life cannot be denied, I am not sure if we could extend it to explain all facets of African psychological life and personality. This "unanimism", as Hountondji (1996: xviii) puts it, is “... the illusion that all men and women in such communal societies speak with one voice and share the same opinion about fundamental issues". A different politics of psychology that will involve more than just substituting Western individualisms with notions of persons and self in cultural contexts is necessary. As such, the current instigations by some, for a shift in the body politic from "psychology in Africa to African psychology" are, in my view, regrettably a call for a move from nothing to nothing else.

\section{References}

Akbar, N (1984) Africentric Social Sciences for human liberation. Journal of Black Studies, 14(4), 395-414.

Alcoff, L (2012) Enrique Dussel's transmodernism. Journal of peripheral cultural production of the Luso-Hispanic world, 1(3), 60-68.

Baloyi, L (2014) From teaching psychology in Africa to teaching African psychology: Challenges, myths and insights. Paper presented at the $6^{\text {th }}$ International Congress on Psychology Education (ICOPE 6), 1-5 August 2014, Northern Arizona University, Arizona, Flagstaff, USA.

Baloyi, L \& Makobe-Rabothata, M (2012) The African conception of death: A cultural implication. Paper presented at the 30th International Congress for Psychology, 22-27 July 2012, Cape Town.

Boidin, C, Cohen, J \& Grosfoguel, R (2012) From university to pluriversity: A decolonial approach to the present crisis of Western universities. Journal of Sociology of Selfknowledge, 1, 1-6.

Burton, M \& Osorio, J M F (2011) Introducing Dussel: The philosophy of liberation and a really social psychology. PINS (Psychology in society), 41, 20-39.

Castro-Gómez, S (2005) La poscolonialidad explicada a los niños. Popayán, Colombia: Editorial Universidad del Cauca.

Cesaire, A (2006) Discurso sobre el colonialismo. Madrid: Akal. 
Dawes, A (1998) Africanisation of psychology: Identities and continents. Psychology in Society, 23, 3-16.

Diop, C A (1991) Civilization or barbarism: An authentic anthropology (translated by Y M Ngemi.) New York: Lawrence Hill.

DuBois, W E B (1940) Dusk of dawn: An essay toward an autobiography of a race concept. Philadelphia: Franklin Library.

Dussel, E (1985) Philosophy of liberation. New York: Orbis Books.

Dussel, E (2002) Posmodernidad y transmodernidad: diálogos con la filosofía de

Gianni Vattimo. Puebla, México. Universidad Iberoamericana / Instituto de Estudios Superiores de Occidente.

Dussel, E (2008a) Twenty theses on politics. Durham, NC: Duke University Press. Fanon, F O (1986) Black skin, White masks. London: Pluto Press (French-1952). Gómez, F \& Dussel, E (2001) Ethics is the original philosophy; or, the barbarian words coming from the third world: An interview with Enrique Dussel. Boundary 2. An international journal of literature and culture, 28(2), 19-73.

Hountondji, P J (1996) African philosophy: Myth and reality. 2nd Edition. Bloomington: Indiana University Press (1983; French-1976).

Juma, J O (2011) African worldviews: Their impact on psychopathology and psychological counselling. Pretoria: UNISA Press.

Kamwangamalu, N M (1999) Ubuntu in South Africa: A sociolinguistic perspective to a pan-African concept. Critical Arts, 13(2), 1-7.

Long, W (2016) On the Africanization of psychology. South African Journal of Psychology, 46 (4), 429-431. DOI: 10.1177/0081246316650853

Madu, S M (1997) Traditional healing systems and (Western) psychotherapy in Africa, in Madu, S M, Baguna, P K \& Prity, A (eds) (1997) African traditional healing: Psychotherapeutic investigation. Kampala, Uganda: Access Communications.

Mashegoane, S (1998) Indigenisation of psychology in South Africa: An awkward entry into the fray. Journal Psychology in Africa, 8, 55-69.

Matoane, M (2012a) Ubuntu therapy: Towards the indigenization of psychology in (South) Africa. Paper presented at the $30^{\text {th }}$ International Congress for Psychology, 22-27 July 2012, Cape Town.

Matoane, M (2012b) Locating context in counselling: The development of indigenous psychology in South Africa. Psychotherapy and Politics International, 10(2), 105-115. 
Matoane, M (2014) Why a psychology that is indigenous to Africa? From Context, to meaning, to identity. Paper presented at the $1^{\text {st }}$ International Congress of Forum of African Psychology, 27-29 March 2014, Polokwane, Limpopo Province.

Mbembe, A (2015) 'Decolonizing Knowledge and the Question of the Archive', Wits Institute for Social and Economic Research, University of the Witwatersrand. Retrieved 20 February 2016: http://wiser.wits.ac.za/system/files/Achille.pdf.

Mhlongo, S (2014) Witchcraft and its relevance for assessment, diagnosis and treatment of mental health conditions: A challenge for the psychology profession. Paper presented at the 20 th Annual South African Psychology Congress, 16-19 September 2014, Durban, KwaZulu-Natal.

Mkabela, N (2015) Ubuntu as a foundation for researching African indigenous psychology. Indilinga - African Journal of Indigenous Knowledge Systems, 14(2), 284-291.

Moll, I (2007) The paradox of "African psychology". Paper presented at the Wits School of Education Research Seminar, 18 September 2007, Johannesburg.

More, M P (1999) What difference does difference make? Alternation, 6(2), 332-349.

Morokane, T H, Baloyi, L \& Siswana, A (2015) An exploration of the role of indigenous songs in psychology: An African perspective. Paper presented at the $21^{\text {st }}$ Annual South African Psychology Congress, 15-18 September 2015, Johannesburg.

Myers, L J (1988). An Afrocentric worldview: Introduction to an optimal psychology. Dubuque, IA: Kendall-Hunt.

Ngobe, A \& Sodi, T (2015) Swati traditional healers' conceptualisation of the causes and treatment methods for mental illness. Paper presented at the $21^{\text {st }}$ Annual South African Psychology Congress, 15-18 September 2015, Johannesburg.

Notshulwana, V \& Franklin, A (2014) Epistemologies of African healing: The relevance of knowing the African traditional healing systems in the practice of mental health. Paper presented at the $20^{\text {th }}$ Annual South African Psychology Congress, 16-19 September 2014, Durban.

Nsamenang, A B (1990) What's in a name? Journal of African Psychology, 1(3), 1-5. Nsamenang, A B (1992) Human development in cultural context: $\mathbf{A}$ third world perspective. London: Sage.

Nsamenang, A B (2002) Adolescence in Sub-Saharan Africa: An image constructed from Africa's triple inheritance, in Brown, B B, Larson, R W \& Saraswathi, T S (eds) (2002) The world's youth: Adolescence in eight regions of the globe. London: Cambridge University Press. 
Nsamenang, A B \& Dawes, A (1998) Developmental psychology as political psychology in sub-Saharan Africa: The challenges of Africanisation. Applied Psychology: An International Review, 47(1), 73-87.

Nwoye, A (2010) A psycho-cultural history of psychotherapy in Africa. Psychotherapy and Politics International, 8(1), 26-43.

Nwoye, A (2015) What is African psychology the psychology of? Theory \& Psychology, 25(1), 96-116.

Ogunmodede, $\mathrm{F}$ (2006) On the historical evolution of schools in African philosophy. Journal of Philosophy and Culture, 1(2), 80-106.

Owomoyela, O (1996) The African difference: Discourse on Africanity and the relativity of cultures. Johannesburg \& New York: Witwatersrand University Press \& Peter Lang.

Ratele, K (2016) Who needs African psychology when we are happy with psychology in Africa? Paper presented at the Rhodes University, Dept of Psychology's Social Change Awards, Grahamstown.

Seedat, M (1997) The quest for liberatory psychology. South African Journal of Psychology, 27, 261-270.

Sefotho, M M (2014) In search of an ethnopsychological model of career guidance and counseling. Paper presented at the 1st International Congress of Forum of African Psychology, 27-29 March 2014, Polokwane, Limpopo Province.

Serpell, R (1992) Afrocentrism: What contribution to science of developmental psychology? Paper presented at the 1st ISSBD International African Workshop on child development and national development in Africa, Yaounde, Republic of Cameroon.

Somni, S H \& Sandlana, N S (2014) Reframing and defining family therapy: Ubuntu perspective. Paper presented at the 1st International Congress of Forum of African Psychology, 27-29 March 2014, Polokwane, Limpopo Province.

Tempels, P (1959) Bantu philosophy. Paris: Presence Africaine.

van Dyk, G A J \& Matoane, M (2010) Ubuntu-Oriented therapy: Prospects for counselling families affected with HIV/AIDS in sub-Saharan Africa. Journal of Psychology in Africa, 20(2), 327-334.

van Dyk, G A J \& Nefale, M C (2005) The split-ego experience of Africans: Ubuntu therapy as a healing alternative. Journal of Psychotherapy Integration, 15(1), 48-66.

Wilson, A N (1999) Afrikan-centered consciousness versus the new world order:

Garvyeism in the age of globalisation. New York: Afrikan World InfoSystem. 